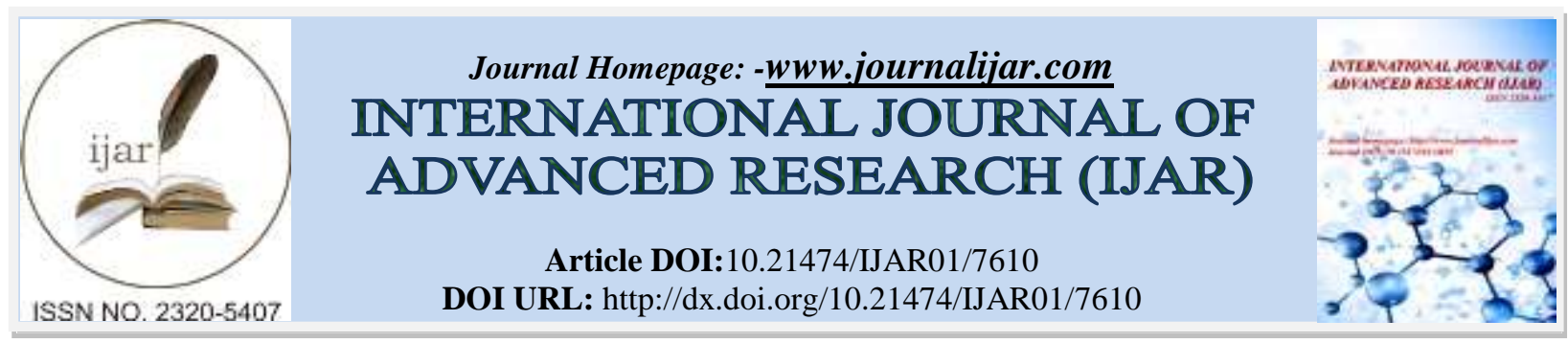

RESEARCH ARTICLE

\title{
CORRELATION BETWEEN THERAPEUTICAL COMMUNICATIONS OF NURSE AND PATIENT SATISFACTION IN INPATIENTS OF GENERAL HOSPITAL MASSENREMPULU IN ENREKANG REGENCY.
}

\author{
Harumin Madani ${ }^{1}$, Sukri Palutturi ${ }^{2}$ and Andi Zulkifli ${ }^{2}$. \\ 1. Graduate School, Faculty of Public Health, Hasanuddin University. \\ 2. Faculty of Public Health, Hasanuddin University.
}

\section{Manuscript Info}

Manuscript History

Received: 22 June 2018

Final Accepted: 24 July 2018

Published: August 2018

Keywords:-

Therapeutic

Satisfaction.

\begin{abstract}
Therapeutic communication is one of the important keys in providing patient care in hospital. Nurses who have the skills to communicate, not only will be easily establish a relationship of trust with the patients, but also preventing illegal businesses, as well as increase patient satisfaction in hospitals. This study aimed to analyze the relationship between therapeutic communication nurse with patient satisfaction inpatien in hospitals massenrempulu enrekang.

The research is an analytic observational study with cross sectional design. The population in this study were all patients in the inpatient Hospitals Massenrempuluinstallations in 2017 with the number of patients as many as 6575 people. Sampling technique in this research used accidental sampling method with a total sample of 226 patients. Datawas collected by questionnaire interviews. Data were analyzed using chi square test and multiple logistic regression.

The results showed that the majority of respondents age 40-49 years (29.2\%), female (58.8\%), junior high school education (36.3\%) and working as farmers $(35.4 \%)$. The analysis showed that there was a relationship of openness $(p=0,040)$ empathy $(p=0,036)$ supportive attitude $(\mathrm{p}=0,036)$ positive attitude $(\mathrm{p}=0,001)$ and equality $(\mathrm{p}=$ $0,000)$ and patient satisfaction. Multivariate analysis with multiple logistic regression showed that the most dominant variable associated with patient satisfaction was equality $(\operatorname{Exp} B=33.041)$. As conclusion that the therapeutic nurse communication is related to patient satisfaction.
\end{abstract}

Copy Right, IJAR, 2018,. All rights reserved.

\section{Introduction:-}

Communication is the main reason of the success of health services in hospitals. In every single of nursing duties, nurse doing the communication as a therapy. This communication becomes very important regarding to become a main tool or method of implementation of nursing process. ${ }^{1}$ Therapeutic communication is the basic of interactive relationships between healthcare workers and patients. ${ }^{2}$

\footnotetext{
${ }^{1}$ Suryani, Komunikasi terapeutik; Teori \& Praktik, ed. e. 2. 2013, Jakarta: EGC

${ }^{2}$ Younis, J.R., S.M. Mabrouk, and F.F. Kamal, Effect of the planned therapeutic communication program on therapeutic communication skills of pediatric nurses. Journal of Nursing Education and Practice, 2015. 5(8): p. 109.
} 
Based on $^{3}$ therapeutic communication is a consciously-planned communication which plan to focused on the patient healing, nurses with communication skills not only will easily build a relationship with the patient trust, also prevent the occurrence of illegal problems, provide professional satisfaction in the nursing services and improve the image of the nursing profession as well as the image of the hospital. While, according to ${ }^{4}$ communication between nurses and patients is very important in establishing therapeutic relationships which determine the quality and process of patient care. Convenience with ${ }^{5}$ said the process of care and the intensity of cooperation between patients and nurses affected by nurse's communication skills.

Patient satisfaction is one of the services quality indicator which be given. Patient satisfaction is a reason which determining the number of more patients and to get loyal patients. Loyal patients will reuse the same health care if they need it again[6]. ${ }^{6}$ In accordance with Suwarto in ${ }^{7}$ patient satisfaction affects the decision making of continuous reuse.

According to, ${ }^{8}$ patient satisfaction on hospital service is affected by one of the factors, is a satisfaction of communication through health workers especially from nurses. A similar statement as told by that the communication of health workers is the determinant of patient satisfaction. Appropriate to Hafizurrachman in ${ }^{10}$, patient satisfaction on health services provided is affected by communication through build a good relationships between nurses and patients

A research conducted by ${ }^{11}$ told that the effect of nurse therapeutic communication on patient satisfaction at hospital inpatients of General Hospital of Sinjai Regency, showed that nurse who implemented therapeutic communication with sufficient nurse empathy value affects patient satisfaction level about $(67.3 \%)$, and research conducted by ${ }^{12}$ about the quality of nurse therapeutic communication and patient satisfaction at Uttarakhand of India Hospital, showed that almost $90 \%$ of patients were satisfied by nurse information that explain about their status and health care, few $(4.5 \%)$ of patients told they were quickly handled and for only $37.3 \%$ of patients said that nurses were polite and humble.

An un-optimal health services at General Hospital Massenrempulu of Enrekang Regency cause many Enrekang District patients who more likely chose to go to General Hospital Lakipada of TanaToraja Regency. This assumption is strengthened with the data of General Hospital of Lakipada of TanaToraja Regency, that the number of Enrekang District patients who visiting to gain a treatment at General Hospital of Lakipada of TanaToraja Regency during 2017 reached 4,224 patients with details of 1,052 inpatients and 3,192 outpatients. Average inpatients about 86-88 people a month. While average of outpatients reached at $250-270$ people a month. ${ }^{13}$.

\footnotetext{
${ }^{3}$ Afnuhazi, R., Komunikasi teraputik dalam keperawatan jiwa. 2014, Jakarta: Gosyen Publishing

${ }^{4}$ Ayman M. Hamdan-Mansour, A.E.A., Imad N. Thultheen, Wisam M. Salim, Saleh N. Azzeghaiby, Muna A. Anani, Patients' satisfaction about nurses' competency in practicing communication skills Life Science Journal 2014. 11(3): p.:339-345

${ }^{5}$ Wloszczak-Szubzda, A. and M.J. Jarosz, Professional communication competences of nurses. Annals of Agricultural and Environmental Medicine, 2012. 19(3).

${ }^{6}$ Supriyanto \& Ermawaty, Pemasaran Industri Jasa Kesehatan. 2010, Yogyakarta: CV. ANDI OFFSET.

${ }^{7}$ Kurniawati, A.L., Hubungan antara mutu pelayanan kesehatan dan komunikasi terapeutik dengan minat kunjung kembali pasien di poliklinik penyakit dalam (studi observasi di rsud panglima sebaya kabupaten paser). Journal of Public Health Publications Indonesia, 2017. 2(3)

${ }^{8}$ Purwanto, E., A. dan D.R. Sulistyastuti. 2008, Metode Penelitian Kuantitatif untuk Administrasi Publik dan Masalah-masalah Sosial, ed. e. pertama. 2008, Yogyakarta: Penerbit Gaya Media.

${ }^{9}$ Al-Abri, R. and A. Al-Balushi, Patient satisfaction survey as a tool towards quality improvement. Oman medical journal, 2014. 29(1): p. 3

${ }^{10}$ Muryani, D., Efektifitas pola komunikasi dalam pelayanan di RSUD Balikpapan, in Ilmu Kesehatan Masyarakat. 2017, Universitas Hasanuddin: Makassar.

${ }^{11}$ Mangindara, Pengaruh komunikasi terapeutik perawat terhadap kepuasan pasien pada instalasi rawat inap di rumah sakit Umum daerah Sinjai Tahun 2014, in Fakultas kesehatan Masyarakat. 2014, universitas Hasanuddin: Makassar

${ }^{12} \mathrm{Negi}, \mathrm{S}$., et al., Quality of nurse patient therapeutic communication and overall patient satisfaction during their hospitalization stay. International Journal of Medical Science and Public Health, 2017. 6(4): p. 675-680.

${ }^{13}$ www.karebatoraja.com. 4.224 Pasien Asal Enrekang Dirawat di RSUD Lakipadada Selama Tahun 2017.2018 [cited 20186 januari].
} 
Based on researcher's first observation in General Hospital Massenrempulu of Enrekang Regency in January of 2018 about the shelter of criticism and suggestion from patient is not available and it was not applied well by hospital management side. This is proven by unavailable of suggestion boxes, satisfaction survey and other tools that can be directly connected with patients' complaints and suggestions during in the hospital, so patients have no tools as a place to suggest some feedbacks and complaints and also patient satisfaction will not be evaluated easily by the hospital management side.

\section{Materials and Methods:-}

\section{Location and Research Design}

This research was conducted at Inpatients Installation of General Hospital Massenrempulu of Enrekang Regency in Inpatients Installation. ${ }^{14}$ The research is analytic observational type with cross sectional study design.

\section{Population and Sample}

The population of this research is all patients in the inpatients installation of General Hospital Massenrempulu of Enrekang Regency in 2017 about 6,575 people. This research used accidental sampling method to determining with the number of sample is 226 subjects. ${ }^{15}$

\section{Method of Collecting Data}

Data obtained from questionnaires that given directly to the respondents. Respondents individually answered all questions on questionnaire sheets from researcher which containing respondent's identities (gender, age, last education and occupation) and question materials about therapeutic communication and patient satisfaction.

\section{Data analysis}

The data is collected, tabulated, inputted, and then analyzed with SPSS program. The results are presented in table form completed with explanation. The data analyzed by Chi-Square Test with significance level $\alpha=0,05$. This research used SPSS software with logistic regression as statistical testing type.

\section{Results:-}

Tabel 1:-Distribution of Respondent's Characteristics

\begin{tabular}{|l|l|l|l|l|}
\hline No. & Respondent's Characteristics & Category & \multicolumn{2}{l|}{ Frequency } \\
\cline { 4 - 5 } & & & N & $\%$ \\
\hline 1 & Age & $<20$ years old & 7 & 3.1 \\
& & $20-29$ years old & 48 & 21.2 \\
& & $30-39$ years old & 53 & 23.5 \\
& & $40-49$ years old & 66 & 29.2 \\
& & $\geq 50$ years old & 52 & 23.0 \\
\hline \multirow{2}{*}{} & & Total & 226 & 100.0 \\
\hline & & Gen & 93 & 41.2 \\
& & Women & 133 & 58.8 \\
\hline 3 & Education Level & Total & 226 & 100,0 \\
& & No school & 58 & 25.7 \\
& & Primary School & 51 & 22.6 \\
& & Junior High School & 82 & 36.3 \\
& & Senior High School & 15 & 6.6 \\
\hline & & Collage & 20 & 8.8 \\
\hline 4 & Occupation & Total & 226 & 100.0 \\
\hline & & Government Employee & 21 & 9.3 \\
& & Entrepreneur & 40 & 17.7 \\
& & Employees & 7 & 3.1 \\
& & Housewife & 70 & 31.0 \\
\hline
\end{tabular}

\footnotetext{
${ }^{14}$ Mundakir, Komunikasi Pelayanan Kesehatan. 2016, Yogyakarta: Indomedia Pustaka

${ }^{15}$ Anastasios, M., Assessment of patient satisfaction in public hospitals in Cyprus: a descriptive study. Health Science Journal, 2013.
} 


\begin{tabular}{|l|l|l|l|l|}
\hline & Farmer & 80 & 35.4 \\
& Unemployed & 8 & 3.5 \\
\hline & Total & 226 & 100.0 \\
\hline
\end{tabular}

Source : Primer Data 2018

Tabel 2:-Relation Between Nurse Openness Dimension and Patient Satisfaction at General Hospital Massenrempulu of Enrekang Regency

\begin{tabular}{|l|r|r|r|r|r|r|r|}
\hline \multirow{2}{*}{ Openness } & \multicolumn{9}{|l|}{ Patient Satisfaction } & \multirow{2}{*}{ Total } & \\
\cline { 2 - 7 } & \multicolumn{2}{|l|}{ Satisfaction } & Dissatisfaction & & \\
\cline { 2 - 7 } & $\mathrm{N}$ & $\%$ & $\mathrm{~N}$ & $\%$ & $\mathrm{~N}$ & $\%$ & \\
\hline Enough & 89 & 63.1 & 52 & 36.9 & 141 & 100 & \multirow{3}{*}{0.040} \\
\hline Less & 41 & 48.2 & 44 & 51.8 & 85 & 100 & \\
\hline Total & 130 & 57.5 & 96 & 42.5 & 226 & 100 & \\
\hline
\end{tabular}

Source : Primer Data 2018

Tabel 3:-Relation Between Nurse Empathy Dimension and Patient Satisfaction at General Hospital Massenrempul Enrekang Regency

\begin{tabular}{|l|r|r|r|r|r|r|r|}
\hline \multirow{2}{*}{ Empathy } & \multicolumn{4}{|l|}{ Patient Satisfaction } & \multicolumn{2}{l|}{ Total } & \multirow{2}{*}{ Statistical Test } \\
\cline { 2 - 7 } & \multicolumn{2}{|l|}{ Satisfaction } & \multicolumn{2}{l|}{ Dissatisfaction } & & \\
\cline { 2 - 7 } & $\mathrm{N}$ & $\%$ & $\mathrm{~N}$ & $\%$ & $\mathrm{~N}$ & $\%$ & \\
\hline Enough & 98 & 62.4 & 59 & 37.6 & 157 & 100 & \multirow{3}{*}{0.036} \\
\hline Less & 32 & 46.4 & 37 & 53.6 & 69 & 100 & \multirow{2}{*}{0.036} \\
\hline Total & 130 & 57.5 & 96 & 42.5 & 226 & 100 & \\
\hline
\end{tabular}

Source: Primer Data 2018

Tabel 4:-Relation Between Nurse Equality Dimension and Patient Satisfaction at General Hospital Massenrempulu of Enrekang Regency

\begin{tabular}{|l|r|r|r|r|r|r|r|}
\hline \multirow{2}{*}{ Equality } & \multicolumn{3}{|l|}{ Patient Satisfaction } & \multirow{3}{*}{ Total } & \multirow{3}{*}{ Statistical Test } \\
\cline { 2 - 7 } & \multicolumn{2}{|l|}{ Satisfaction } & \multicolumn{2}{l|}{ Dissatisfaction } & & \\
\cline { 2 - 7 } & $\mathrm{N}$ & $\%$ & $\mathrm{~N}$ & $\%$ & $\mathrm{~N}$ & $\%$ & \\
\hline Enough & 120 & 71.0 & 49 & 29.0 & 169 & 100 & \multirow{3}{*}{0.040} \\
\hline Less & 10 & 17.5 & 47 & 82.5 & 57 & 100 & \\
\hline Total & 130 & 57.5 & 96 & 42.5 & 226 & 100 & \\
\hline
\end{tabular}

Source : Primer Data 2018

\section{Characteristics of Respondents}

Characteristics of respondents are specific characteristics that bounded to the respondent's themselves includes age, gender, last education and occupation shown in table 1. The Highest Age Group is 40-49 years about 66 respondents (29.2\%) and the Lowest Age Group is <20 years had 7 respondents (3.1\%). Most of them were women had 133 respondents $(58.8 \%)$ and 93 respondents $(41.2 \%)$ were men. The majority of respondents have education level at junior high school about 82 subjects $(36,3 \%)$ and senior high school about 15 respondents $(15.6 \%)$. And most of them work as farmer about 80 respondents $(35.4 \%)$ and about 8 respondents $(3.5 \%)$ unemployed.

\section{Openness}

Table 2 shows that 141 respondents assume the openness of nurses is good enough, the number of respondents satisfied of using health services at Inpatients Installation of General Hospital Massenrempulu of Enrekang Regency is 89 respondents $(63.1 \%)$, and 52 respondents (36.9\%) experienced the dissatisfaction feeling. While the number of respondents who believe that nurses were less opened is 85 patients and about 41 respondents (48.2\%) got satisfiedfeeling about health services at General Hospital Massenrempulu of Enrekang Regency and 44 respondents (51.8\%) expressed dissatisfaction.

The result of statistical test using chi-square is obtained $\mathrm{p}$ value $=0.040$, because probability value $\alpha<0.05$, Ha is accepted which means that there is relation between nurse openness dimension and patient satisfaction at General Hospital Massenrempulu of Enrekang Regency 


\section{Empathy}

Table 3 describes that from 157 respondents who assume the nurses empathy is good enough where as the number of respondents satisfied of using health services at Inpatients Installation of General Hospital Massenrempulu of Enrekang Regency is 98 people (62.4\%) and expressed dissatisfaction is 59 respondents (37.6\%) . While the number of respondents who believe that nurses were less empathy is 69 patients and about 59 respondents (37.6\%) feel satisfied to use health services at General Hospital Massenrempulu of Enrekang Regency and 37 people (53.6\%) expressed dissatisfaction.

The result of statistical test using chi-square is obtained $\mathrm{p}$ value $=0.036$, because probability value $\alpha<0.05$, Ha is accepted which means that there is relation between nurse empathy dimension and patient satisfaction at General Hospital Massenrempulu of Enrekang Regency

\section{Equality}

Table 4 describes that from 169 respondents who assume the nurses equality is good enough where as the number of respondents satisfied of using health services at Inpatients Installation of General Hospital Massenrempulu of Enrekang Regency is 120 people (71.0\%) and expressed dissatisfaction about 49 respondents (29.0\%). While the number of respondents who believe that nurses were less equality is 57 patients and about 10 respondents (17.5\%) feel satisfied to use health services at General Hospital Massenrempulu of Enrekang Regency and 47 people (82.5\%) expressed dissatisfaction.

The result of statistical test using chi-square is obtained $\mathrm{p}$ value $=0.000$, because probability value $\alpha<0.05$, Ha is accepted which means that there is relation between nurse equality dimension and patient satisfaction at General Hospital Massenrempulu of Enrekang Regency

\section{Discussion:-}

The quality of openness based on various aspects of interpersonal communication. Firstly, an effective interpersonal communicators need to be open to the person whom they interacting with. It doesn't mean that people should immediately tell all of their personal background. In otherwise, there should be a willingness to speak up about information that untold, as long as it is appropriate. Motivation of self-expression which is beneficial and productive for all relevant parties, appropriate that connected to the circumstance and the relationship between speaker and listener and its personal issues, equal self-disclosure. Self-disclosure or introductions by healthcare workers before providing healthcare is needed.

Openness encourages forming of understanding, mutual trust, and build interpersonal relationships. Communicators and communicants express their ideas or though even problem straightly (nothing covered) and openly without fear or shame. Both knowing and understanding each other. According to ${ }^{16}$ nurses should be open in providing information about theirselves, ideal self, feelings, attitudes and values they believed. Nurses openly speak up about a useful experience for client therapy.

Patients who are satisfied with the health services provided by the nurses because the openess of nurse to patients by providing clear information, advice and counseling about the patient's health condition and nurses also explain details of each nursing action that will be given to patients.

Based on the results of this studyshow that $63.1 \%$ of respondents said they were satisfied with the openness of nurses and $36.9 \%$ of respondents felt less satisfied with the openness of nurses in the Inpatients Installation of General Hospital Massenrempulu of Enrekang Regency.

The results show that there was a relationship between nurse openness dimension and patient satisfaction at Inpatients Installation of General Hospital Massenrempulu of Enrekang Regency $(p=0.040)$ and pointed out that openness has exp value (B) 1.127 times bigger than other variable. Patients who satisfied with the health services provided by the nurse regarding to the openness of nurse has been applied to the patient by delivering clear information, advice and counseling about patient's medical history and the nurse also explains every single of

\footnotetext{
${ }^{16}$ Mundakir, Komunikasi Pelayanan Kesehatan, op.cit
} 
nursing actions that will be given to the patient. Based on ${ }^{17}$, nurses have to provide information because it is the right of a patient should have.

This research is in line with ${ }^{18}$, which explains that more respondents are satisfied with the openness of doctors than who dissatisfied. Openness of doctor's communication can be seen from the way the doctor communicates by explain any information which is necessary for patients during consultation and or treatment and willing and easily to respond all information that patients received

Similar with research held by ${ }^{19}$ shows $90 \%$ of patients were satisfied with the nurse's openness in giving appropriate information on the health status and patients treatment in the state hospital ward of Uttarakhand in India.

There is a relationship in this research in case when nurse communicate widely open, it will give the benefit to the patient to involve cooperation and give some support. That is why, the next action of nurse will be better. Patients will be more cooperative in expressing problems widely open (not covered up). Expressing out is something needed for the well and opened communication. According to ${ }^{20}$ that one of the concepts to gaining patient satisfaction is the openness of nurses and nurses / doctors in terms of the patient's right to receive their health information.

According to ${ }^{21}$ stated that honesty is important in therapeutic communication, because less of honesty cause it impossible to build trust relationships. Someone will put belief in others who is openes and has a natural response that is not forced, in the other hand he or she will be careful to the opponent who is too respect or may hide the real feeling that is not honest. For instance, nurses must honestly answer the patient's question about progress of health record, or if nurses are unable to explain, they could suggest the client to ask directly the doctor who authorized.

The common relation in this study regarding to the case of the openess of nurses which will give benefits to clients in order for cooperation support and contribution. Thus the next nursing action will be better. Patients will be more cooperative to expressing easily the problem (not covered up) even though there are still patients who cover the problem but nurses should continuesly trying to comfort the openness circumstance between nurses and patients to easily knowing and understanding each other. Openness is necessary to make an open communication. Openness benefits the healthy interpersonal relationships. The effectiveness of a relationship based on how much we disclose ourselves to receiving and informing others.

Based on ${ }^{22}$, said that effective communication begins with an introduction, the nurses introduction to patients is the basis of establishing further therapeutic relationships. Patient honesty is needed for healing process as this becomes the main reason for openness between nurses and patients can be esatbalished. Without a nurse's honesty, it is impossible to have a trusting relationship between nurses and patients to be established and the aim of interpersonal communication of the nurse and patient will be inhibited.

Empathy is a sense of care and special attention of staff to every healthcare services user, can understand their needs, and easily to be able to contacted at any time if healthcare service users need to get some helps.

Empathy pointed in this research is the ability of a person to 'understand' what is being experienced by others in a certain time, from other person's perspective, through the other person's perception. People who are empathic will definitely be able to understand the motivations and experiences of others, their feelings and attitudes, and also their hopes and desires for the future.

Empathy can be communicated through verbal or nonverbal types. Nonverbal through showing: active involvement with patients through convenient facial expressions and gestures, focused concentration instance eye contact, an

\footnotetext{
${ }^{17}$ Anastasios, M., Assessment of patient satisfaction in public hospitals in Cyprus: a descriptive study, op.cit

${ }^{18}$ Asdawati, S., A. Indahwaty, Kapalawi, Irwandy, Gambaran kepuasan pasien dalam pelaksanaan komunikasi efektif dokter di rsud kota makassar. Bagian Manajemen Rumah Sakit Fakultas Kesehatan Masyarakat Unhas 2014.

${ }^{19}$ Negi, S., et al., Quality of nurse patient therapeutic communication and overall patient satisfaction during their hospitalization stay. International Journal of Medical Science and Public Health, 2017. 6(4): p. 675-680.

${ }^{20}$ Anastasios, M., Assessment of patient satisfaction in public hospitals in Cyprus: a descriptive study, op.cit

${ }^{21}$ Suryani, Komunikasi terapeutik; Teori \& Praktik, ed. e. 2. 2013, Jakarta: EGC

${ }^{22}$ Guest, M., How to introduce yourself to patients. Nursing Standard (2014+), 2016. 30(41): p. 36.
} 
attentive posture, and physical closeness, and also proper touch or flattery. Verbal with: making a tentative statement and not a question, do the self-expression which nurses feel what the patients feel.

According to ${ }^{23}$, empathy is the ability to through the life of clients in order to feel their thoughts and feelings. Nurses consider through the client's perspective, sense through the client's feelings and then identify the client's problem and help clients resolve the problem. Empathy is something that is honest, sensitive, and not artificial (objective) based on what clients are experienced. For clients, empathy is very important because in ill condition, clients experience confusion and clogged thinking unclearly so it will be needed understanding how to help clients to complete the conditions that occur. For healthcare workers, empathy is important regarding to assist to understand the conditions and problems facing the client.

Patients who are satisfied with the healthcare services provided by nurses mostly based on how patients feel about being well received by nurses. Nurses respond immediately when patients need healthcare service. Nurses will be care enough if they ask routinely how patient's condition and be kind in order to make patients quite feel comfortable treated in the room. Instead of making patients dissatisfied when patients want to complain about healthcare services received during treatment and want to consult about their health problems, sometimes nurses give less attention to listen to the patient's story and immediately willing to end the conversation with patients. Eventually, patient impressions about nurses are less patient, less understanding and unable to feel what patient experienced.

The results show that there was a relationship between nurse empathy dimension with patient satisfaction at Inpatients Installation of General Hospital Massenrempulu of Enrekang Regency $(p=0.036$ ). The patient more satisfied with the health services provided by the nurse because the patient feels well handled by nurse. The nurse responds immediately on every patient service needs. Nurses well concerned if regularly ask the patient's condition and act friendly to make the patient comfortably treated in the room.

Basically, this caused of every patient desire to be treated individually or specifically, therefore nurses need the sense of empathy to offering nursing care as a main tool to meet the patient's expectation of special treatment, so the satisfaction will build on patient perspective of the treating of nursing services that they received.

This research is the same with research conducted $b^{24}$, who concluded that there is a relationship between empathy with satisfaction of inpatients of Bhayangkara Hospital of Tk III Manado. This research also describes that patients who are mostly satisfied and satisfied of the empathy dimension is higher than them who dissatisfied.

In the same case with research conducted by ${ }^{25}$, explained that about $67.3 \%$ respondents were satisfied with the manner of empathy nurse. Which concluded that there is a relation between empathy with patient satisfaction at Inpatients of Installation in General Hospital with result of statistical test by using square-test obtained $\mathrm{p}$ value $=$ $0.000<0.05$.

To create a best quality service and emotional bond with patients, the hospital in case providing health services should be able to consider well all patient's problem include recall their disease history and previous complaints, and able to be a good listener. ${ }^{26}$ Empathy as a basic component of all therapeutic relationships and main factors in providing a qualified health care

As a nurse, they must eager to know exactly what the patients think. Since patientsthought that empathy is the main component of all therapeutic relationships and the major success reasons in establishing communication and contributing support to what patients are feeling.

In every situation, sometimes people feelings are in an inequality. Some are smarter, richer, more handsome and gorgeous and also have more advantages than others. There aren't two people who are truly equal in every single

\footnotetext{
${ }^{23}$ Mundakir, Komunikasi Pelayanan Kesehatan, op.cit

${ }^{24}$ Chika, P., A.A. Rumayar, and S. Engkeng, Hubungan Antara Kepuasan Pasien terhadap Kualitas Pelayanan Perawat di Ruang Rawat Inap Rumah Sakit Bhayangkara TK III Manado. Media Kesehatan, 2017. 9(3).

${ }^{25}$ Mangindara, Pengaruh komunikasi terapeutik perawat terhadap kepuasan pasien pada instalasi rawat inap di rumah sakit Umum daerah Sinjai Tahun 2014, op.cit

${ }^{26}$ Anastasios, M., Assessment of patient satisfaction in public hospitals in Cyprus: a descriptive study, op.cit
} 
thing. Given the inequality that is absolutely exist so more effective therapeutic communication is needed which can make the circumstance or atmoshpere more equal, where every human beings believe in heart deepth that each of us is worth and has self-esteem where everyone have advantages and disadvantages. So that interpersonal relationships can tolerate differences.

An effeicient communication is if it occurs in an equal position. Similarly with ${ }^{27}$, that equality, is a communication that put themselves in balance with the client. The scheme of equal communication is will encourage the comfort and interest feeling from the client to participate in communicating. This happens if between nurses and clients exchanged trust and mutual respect. Equality in this case does not require that we accept and approve without doubty of all others' nonverbal and verbal behavior, but equality means accepting others, or, equality asks to give unconditional positive rewards to others.

In performing healthcare service activities, nurses cannot devoid relation to patients because during communication process there is an information told, exchange of feelings and thoughts. Communication problems and obstacles are common in establishing these relationships. Different health status and authority in healthcare services found frequently. Where the position of nurses who claim having power, capability, and authority in healthcare services cause nurses are more dominant in establishing communication and relationships with patients.

Based on table 17 shows that 169 respondents who assessed the equality of nurses and patients satisfaction at at Inpatients Installation of General Hospital Massenrempulu of Enrekang Regency who expressed satisfaction about 120 people $(71.0 \%)$ and who expressed dissatisfactionabout 49 people $(29.0 \%)$.

Patients who are satisfied with the healthcare services provided by nurses are mostly caused by respect and appreciate that showed from nurses to patients and without discriminate the position between nurses and patients while communicating. Nurses more precede justice regardless of social status and gender in order to assist satisfaction feeling from patients and their family.

On the contrary, patients who are less satisfied with the healthcare services provided by nurses because the nurses are unable to performance intimacy with patients and it seems nurses do not consider patients as a friend because between nurses and patients are still acting like a stranger. Whereas, establishing closeness between nurses and patients in communicating is essential for the ease of personal relationships. Clumsy makes it more difficult to establish communication between nurses and patients.

The results showed that there was a relationship between the dimensions of equality with patient satisfaction at inpatient installation of General Hospital Massenrempulu of Enrekang Regency $(\mathrm{p}=0.000)$. It concluded that patient satisfaction is highly related in equality of interpersonal communication of health worker especially nurses and patient. This is caused of the patient satisfied with health services gained and there is no difference position between nurse and patient while communicating.

This research is similar with research conducted by ${ }^{28}$, at Pandan Community Health Centers which showed that there is a significant relationship between patient satisfaction and equality which statistical test of pearson chisquare gained $p$ value $=0.000<\alpha=0.05$. Patient satisfaction is extremely connected to equality of interpersonal communication of nurse to patient. In the same case with ${ }^{29}$ that the nurses who serve with no distinguish of the patient's status well affects the level of patient satisfaction.

Other studies also emphasis the same point, from ${ }^{30}$ told that interpersonal communication between nurses and patients in Thalasaemia Center shows the existence of equality between the two parties.

\footnotetext{
${ }^{27}$ Mundakir, Komunikasi Pelayanan Kesehatan, op.cit

${ }^{28}$ Andayani, L.S., The Factors Associated with Health Workers in Interpersonal Communication Satisfactions of Outpatient Health Center Pandan Tapanuli District Middle of 2014 Working Area Pandan Kec. Pandan 2014. Kebijakan, Promosi Kesehatan dan Biostatiskik, 2015. 1(2).

${ }^{29}$ Ramadhan, A.P. and W. Wirman, Komunikasi Interpersonal Perawat Dan Pasien Thalasaemia Di Thalasaemia Center RSUD Arifin Achmad Pekanbaru. Jurnal Online Mahasiswa Fakultas Ilmu Sosial dan Ilmu Politik Universitas Riau, 2016. $3(2)$ : p. 1-13. ${ }^{30}$ Narenjiha, M., et al., The importance of physicians' communication skills and patients' satisfaction. Thrita, 2012. 1(2): p. 5761.
} 
Respectful and appreciative is the attitude that patient expected from the nurse in communicating, no discriminating age, nor socioeconomic status. Being fair in providing health care services is the basis for establishing the therapeutic communication and preventing the discriminative treatment of patients

\section{Conclusion:-}

The results of research can be concluded that there was relation between nurse openness dimension with patient satisfaction $(\mathrm{p}=0.040)$. There was relation between nurse empathy dimension and patient satisfaction $(\mathrm{p}=0.036)$ and There was relation between equality dimension of nurse to patient satisfaction $(\mathrm{p}=0.000)$. The suggestion may be given from this research, nurse in need to have skill and knowledge about interpersonal communication, and also improve the interpersonal communication skill as effort to gain a high quality of nurse personality.

\section{References:-}

1. Suryani, Komunikasi terapeutik :teori \& praktik, ed. e. 2. 2013, Jakarta: EGC.

2. Younis, J.R., S.M. Mabrouk, and F.F. Kamal, Effect of the planned therapeutic communication program on therapeutic communication skills of pediatric nurses. Journal of Nursing Education and Practice, 2015. 5(8): p. 109.

3. Afnuhazi, R., Komunikasi teraputik dalam keperawatan jiwa. 2014, Jakarta: Gosyen Publishing.

4. Ayman M. Hamdan-Mansour, A.E.A., Imad N. Thultheen, Wisam M. Salim, Saleh N. Azzeghaiby, Muna A. Anani, Patients' satisfaction about nurses' competency in practicing communication skills Life Science Journal 2014. 11(3): p.:339-345.

5. Wloszczak-Szubzda, A. and M.J. Jarosz, Professional communication competences of nurses. Annals of Agricultural and Environmental Medicine, 2012. 19(3).

6. Supriyanto \& Ermawaty, Pemasaran Industri Jasa Kesehatan. 2010, Yogyakarta: CV. ANDI OFFSET.

7. Kurniawati, A.L., Hubungan antara mutu pelayanan kesehatan dan komunikasi terapeutik dengan minat kunjung kembali pasien di poliklinik penyakit dalam (studi observasi di rsud panglima sebaya kabupaten paser). Journal of Public Health Publications Indonesia, 2017. 2(3).

8. Purwanto, E., A. dan D. R. Sulistyastuti. 2008, Metode Penelitian Kuantitatif untuk Administrasi Publik dan Masalah-masalah Sosial, ed. e. pertama. 2008, Yogyakarta: Penerbit Gaya Media.

9. Al-Abri, R. and A. Al-Balushi, Patient satisfaction survey as a tool towards quality improvement. Oman medical journal, 2014. 29(1): p. 3.

10. Muryani, D., Efektifitas pola komunikasi dalam pelayanan di RSUD Balikpapan, in Ilmu Kesehatan Masyarakat. 2017, Universitas Hasanuddin: Makassar.

11. Mangindara, Pengaruh komunikasi terapeutik perawat terhadap kepuasan pasien pada instalasi rawat inap di rumah sakit Umum daerah Sinjai Tahun 2014, in Fakultas kesehatan Masyarakat. 2014, universitas Hasanuddin: Makassar.

12. Negi, S., et al., Quality of nurse patient therapeutic communication and overall patient satisfaction during their hospitalization stay. International Journal of Medical Science and Public Health, 2017. 6(4): p. 675-680.

13. www.karebatoraja.com. 4.224 Pasien Asal Enrekang Dirawat di RSUD Lakipadada Selama Tahun 2017. 2018 [cited 20186 januari].

14. Mundakir, Komunikasi Pelayanan Kesehatan. 2016, Yogyakarta: Indomedia Pustaka

15. Anastasios, M., Assessment of patient satisfaction in public hospitals in Cyprus: a descriptive study. Health Science Journal, 2013.

16. Asdawati, S., A. Indahwaty,Kapalawi, Irwandy, Gambaran kepuasan pasien dalam pelaksanaan komunikasi efektif dokter di rsud kota makassar. Bagian Manajemen Rumah Sakit Fakultas Kesehatan Masyarakat Unhas 2014.

17. Abedi, G., et al., Applying a Model of Patient's Right in the State Hospital, Sari, Iran. International Journal of Collaborative Research on Internal Medicine \& Public Health, 2012. 4(2): p. 103-110.

18. Guest, M., How to introduce yourself to patients. Nursing Standard (2014+), 2016. 30(41): p. 36.

19. Chika, P., A.A. Rumayar, and S. Engkeng, HUBUNGAN ANTARA KEPUASAN PASIEN TERHADAP KUALITAS PELAYANAN PERAWAT DI RUANG RAWAT INAP RUMAH SAKIT BHAYANGKARA TK III MANADO. Media Kesehatan, 2017. 9(3).

20. Fandy Tjiptono, P.D., Service Management, Mewujudkan Layanan Prima ed. E. kedua. 2012, yogyakarta: Penerbit Andi.

21. Derksen, F., J. Bensing, and A. Lagro-Janssen, Effectiveness of empathy in general practice: a systematic review. Br J Gen Pract, 2013. 63(606): p. e76-e84. 
22. Andayani, L.S., The Factors Associated with Health Workers in Interpersonal Communication Satisfactions of Outpatient Health Center Pandan Tapanuli District Middle of 2014 Working Area Pandan Kec. Pandan 2014. Kebijakan, Promosi Kesehatan dan Biostatiskik, 2015. 1(2).

23. Narenjiha, M., et al., The importance of physicians' communication skills and patients' satisfaction. Thrita, 2012. 1(2): p. 57-61.

24. Ramadhan, A.P. and W. Wirman, Komunikasi Interpersonal Perawat Dan Pasien Thalasaemia Di Thalasaemia Center RSUD Arifin Achmad Pekanbaru. Jurnal Online Mahasiswa Fakultas Ilmu Sosial dan Ilmu Politik Universitas Riau, 2016. 3(2): p. 1-13. 